JOURNAL OF HEALTH RESEARCH SCIENCE

VOL. 01 NO. 02, DESEMBER 2021

DOI: $\underline{10.34305 / J H R S . V 1 I 02.372}$
Ciptaan disebarluaskan di bawah

Lisensi Creative

CommonsAtribusi-NonKomersial-

BerbagiSerupa 4.0

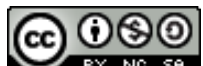

\title{
HUBUNGAN PERSEPSI IBU TENTANG IMUNISASI DENGAN KELENGKAPAN IMUNISASI DASAR PADA BAYI USIA 9-11 BULAN DI DESA PANINGGARAN KECAMATAN DARMA TAHUN 2021
}

\author{
STIKes Kuningan \\ iikhikmah99@gmail.com
}

Iik Hikmah Nurharpiyani, Indrayani, Hamdan

\begin{abstract}
Abstrak
Indikator capaian program imunisasi pada bayi yaitu tercapainya target "Universal Child Immunization" atau UCI, yang mana UCI merupakan keadaan pencapaian Imunisasi Dasar Lengkap untuk semua bayi (anak dibawah satu tahun). Desa Paninggaran merupakan desa dengan capaian UCI masih dibawah target sebesar 33,33\% dengan hanya mencapai 19,6\%. Tujuan penelitian ini adalah untuk mengetahui hubungan persepsi ibu tentang imunisasi dengan kelengkapan imunisasi dasar pada bayi usia 9-11 bulan di Desa Paninggaran Kecamatan Darma Tahun 2021. Metode penelitian ini menggunakan analitik dengan rancangan cross sectional, populasi dalam penelitian ini ibu yang memiliki bayi usia 9-11 bulan. Teknik pengambilan sampel yaitu Total Sampling, dengan jumlah 56 orang, instrumen penelitian menggunakan lembar kuesioner, analisis menggunakan uji statistik univariat dan bivariat. Berdasarkan hasil analisis uji statistik univariat menunjukkan bahwa responden yang kelengkapan imunisasi dasar pada bayinya lengkap yaitu 25 responden $(44,6 \%)$ dan yang tidak lengkap yaitu 31 responden $(55,4 \%)$. Hasil analisis uji statistik bivariat menunjukkan nilai $\mathrm{p}=0,000(<0,05)$. Dapat disimpulkan bahwa ada hubungan antara persepsi ibu tentang imunisasi dengan kelengkapan imunisasi dasar pada bayi usia 9-11 bulan di desa Paninggaran kecamatan Darma tahun 2021. Diharapkan kedepannya petugas Puskesmas dan Poskesdes dapat meningkatkan penyuluhan tentang pentingnya kelengkapan imunisasi dasar pada bayi secara tepat dan menyeluruh tidak hanya ke ibu bayi saja tapi pada keluarga maupun masyakarat secara luas.
\end{abstract}

Kata Kunci $\quad$ : Persepsi, Kelengkapan Imunisasi Dasar, Bayi.

\section{Pendahuluan}


JOURNAL OF HEALTH RESEARCH SCIENCE

VOL. 01 NO. 02, DESEMBER 2021

DOI: $\underline{10.34305 / J H R S . V 1 I 02.372}$

\begin{tabular}{|c|c|c|}
\hline Imunisas & merupakan & suatu \\
\hline program yang & dengan & sengaja \\
\hline memasukkan & antigen lemah & agar \\
\hline merangsang & antibodi & sehingga \\
\hline tubuh dapat & resisten terhadap & \\
\hline
\end{tabular}

Keberhasilan program imunisasi dapat memberikan cakupan imunisasi yang tinggi dan memelihara imunitas, namun cakupan imunisasi dasar dipengaruhi oleh berbagai faktor yaitu salah satunya faktor pendorong dimana seorang ibu memiliki keputusan untuk melakukan atau tidak melakukan imunisasi kepada anak nya antara lain usia ibu, tingkat pendidikan ibu, tingkat kepercayaan terhadap dampak buruk pemberian imunisasi, status pekerjaan ibu, tingkat pengetahuan ibu, dan dukungan keluarga (Bernsen et al., 2011).

Berdasarkan hasil penelitian yang dilakukan oleh Dewi et al. (2013) di Kelurahan Parupuk Tabing Kota Padang diketahui bahwa persentase pemberian imunisasi dasar lengkap lebih banyak pada ibu yang mempunyai pengetahuan cukup yaitu sebesar $87,5 \%$ dibandingkan dengan ibu yang berpengetahuan kurang yaitu sebesar 4,3\%. Hal ini menunjukkan bahwa peran pengetahuan Ibu tentang imunisasi dasar sangat berpengaruh terhadap
Ciptaan disebarluaskan di bawah Lisensi Creative

CommonsAtribusi-NonKomersialBerbagiSerupa 4.0

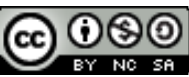

kelengkapan imunisasi dasar pada bayi (Dewi et al., 2013).

Salah satu indikator capaian program imunisasi pada bayi yaitu tercapainya target "Universal Child Immunization" atau UCI, yang mana UCI merupakan keadaan pencapaian Imunisasi Dasar Lengkap untuk semua bayi (anak dibawah satu tahun). Cakupan UCI Jawa Barat tahun 2019 $\begin{array}{llll}\text { sebesar } & 93,74 \% & \text { sebanyak } & 5.584\end{array}$ desa/kelurahan dari 5.957 yang ada di Jawa Barat. Dan untuk Kabupaten Kuningan Cakupan Desa/Kelurahan UCI menurut Kabupaten/Kota di Provinsi Jawa Barat Tahun 2019 adalah sebesar 96,0\% (Dinkes, 2019).

Berdasarkan data dari laporan cakupan imunisasi dasar pada bayi per-bulan Mei tahun 2021 di Puskesmas Darma bahwa untuk capaian UCI tahun 2021 di Kecamatan Darma yaitu 78,9\%. Di Kecamatan Darma masih ada desa yang belum mencapai target UCI sebesar 33,33\%. Adapun Desa Paninggaran merupakan desa dengan capaian UCI masih dibawah target dengan hanya mencapai $19,6 \%$, sehingga data tersebut menunjukan pelaksanaan pemberian imunisasi dasar lengkap pada bayi di Desa Paninggaran masih belum mencapai target. 
JOURNAL OF HEALTH RESEARCH SCIENCE

VOL. 01 NO. 02, DESEMBER 2021

DOI: $\underline{10.34305 / J H R S . V 1 I 02.372}$

\section{Metode}

Penelitian ini menggunakan pendekatan analitik dengan jenis penelitian Kuantitatif dan menggunakan rancangan cross sectional. Studi cross sectional merupakan salah satu studi observasional untuk menentukan hubungan antara faktor risiko dan penyakit (Heriana, 2018).

Dalam penelitian ini yang dijadikan populasi adalah ibu yang memiliki bayi usia 9-11 bulan di desa Paninggaran sebanyak 56 orang, dan sampel dalam penelitian ini adalah total sampel yaitu ibu yang memiliki bayi usia 9-11 bulan di desa Paninggaran sebanyak 56 orang. Sampel adalah sebagian dari populasi karena ia merupakan bagian dari populasi tentulah ia memiliki ciri-ciri
Ciptaan disebarluaskan di bawah Lisensi Creative

\section{CommonsAtribusi-NonKomersial-} BerbagiSerupa 4.0 yang dimiliki oleh populasinya (Badriah, 2019). Variabel bebas dalam penelitian ini adalah Persepsi Ibu tentang Imunisasi, dan variabel terikatnya adalah Kelengkapan Imunisasi Dasar pada Bayi usia 9-11 Bulan.

Instrumen adalah alat pengumpulan data yang telah baku atau alat pengumpulan data yang memiliki standar validitas dan reliabilitas (Badriah, 2019). Instrumen penelitian yang digunakan berupa lembar kuesioner yang terdiri dari 15 butir pertanyaan dimana pertanyaan nomer 1-5 berupa pertanyaan positif dan pertanyaan nomer 6-15 berupa pertanyaan negatif.

\section{Hasil}

Analisis Univariat

Tabel 1 Persepsi Ibu tentang Imunisasi dan Kelengkapan Imunisasi Dasar pada Bayi usia 9-11 bulan di Desa Paninggaran Kecamatan Darma tahun 2021

\begin{tabular}{|c|c|c|c|}
\hline \multirow{2}{*}{\multicolumn{4}{|c|}{$\begin{array}{l}\text { Variabel } \\
\text { Persepsi Ibu }\end{array}$}} \\
\hline & & & \\
\hline & Positif & 34 & 60,7 \\
\hline & Negatif & 22 & 39,3 \\
\hline & Total & 56 & 100,0 \\
\hline \multirow[t]{4}{*}{2.} & Kelengkapan I & & \\
\hline & Lengkap & 25 & 44,6 \\
\hline & Tidak Lengkap & 31 & 55,4 \\
\hline & Total & 56 & 100,0 \\
\hline
\end{tabular}

Sumber : Hasil Penelitian Data Primer Tahun 2021

Berdasarkan Tabel 1 menunjukkan bahwa sebagian besar responden memiliki persepsi positif tetang imunisasi yaitu 34 responden $(60,7 \%), \quad$ sedangkan yang memiliki persepsi negatif tentang imunisasi yaitu 22 responden $(39,3 \%)$, dan sebagian besar responden yang memiliki bayi usia 911 bulan yang telah diimunisasi dasar 
JOURNAL OF HEALTH RESEARCH SCIENCE

VOL. 01 NO. 02, DESEMBER 2021

DOI: $10.34305 / \mathrm{JHRS} . \mathrm{V} 1 \mathrm{I} 02.372$
Ciptaan disebarluaskan di bawah

Lisensi Creative

CommonsAtribusi-NonKomersial-

BerbagiSerupa 4.0

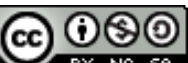

lengkap yaitu 25 responden (44,6\%), usia 9-11 bulan yang imunisasinya tidak sedangkan responden yang memiliki bayi lengkap yaitu 31 responden $(55,4 \%)$.

Analisis Bivariat

Tabel 2 Hubungan Persepsi Ibu tentang Imunisasi dengan Kelengkapan Imunisasi Dasar pada Bayi usia 9-11 bulan di Desa Paninggaran Kecamatan Darma tahun 2021

\begin{tabular}{|c|c|c|c|c|c|c|c|c|}
\hline \multirow{3}{*}{$\begin{array}{l}\text { Persepsi Ibu } \\
\text { tentang } \\
\text { Imunisasi }\end{array}$} & \multicolumn{4}{|c|}{$\begin{array}{c}\text { Kelengkapan Imunisasi Dasar pada } \\
\text { Bayi usia } 9-11 \text { bulan }\end{array}$} & \multirow{2}{*}{\multicolumn{2}{|c|}{ Total }} & \multirow{3}{*}{$p$-value } & \multirow{3}{*}{$\begin{array}{c}\text { OR }(95 \% \\
\text { CI })\end{array}$} \\
\hline & \multicolumn{2}{|c|}{ Lengkap } & \multicolumn{2}{|c|}{ Tidak Lengkap } & & & & \\
\hline & $\mathrm{f}$ & $\%$ & $\mathrm{f}$ & $\%$ & $\mathrm{~N}$ & $\%$ & & \\
\hline Positif & 25 & 73,5 & 9 & 26,5 & 34 & 100,0 & & 3,778 \\
\hline Negatif & 0 & 0 & 22 & 39,3 & 22 & 100,0 & 0,000 & $(2,157-$ \\
\hline Total & 25 & 44,6 & 31 & 55,4 & 56 & 100,0 & & $6,615)$ \\
\hline
\end{tabular}

Sumber : Hasil Penelitian Data Primer Tahun 2021

Berdasarkan Tabel 2 menunjukkan

bahwa dari 34 responden yang yang memiliki persepsi positif tentang imunisasi sebagian besar kelengkapan imunisasi dasar pada bayinya lengkap yaitu $25(73,5 \%)$ dan yang tidak lengkap yaitu $9(26,5 \%)$. Dan dari 22 responden yang memiliki persepsi negatif tentang imunisasi secara keseluruhan kelengkapan imunisasi dasar pada bayinya tidak lengkap yaitu $22(39,3 \%)$.

Berdasarkan uji statistik diperoleh $p$ value sebesar 0,000 atau $(p \leq 0,05)$, maka dapat diartikan bahwa ada hubungan antara persepsi ibu tentang imunisasi dengan kelengkapan imunisasi dasar pada bayi usia 9-11 bulan di Desa Paninggaran Kecamatan Darma tahun 2021. Nilai odds ratio (OR) yaitu 3,778 artinya ibu yang memiliki persepsi negatif tentang imunisasi mempunyai peluang berisiko 3,778 kali untuk ibu tidak melengkapi imunisasi dasar pada bayinya dibandingakan responden yang memiliki persepsi positif tentang imunisasi.

\section{Pembahasan}

1. Gambaran Persepsi Ibu tentang Imunisasi

Dari hasil penelitian didapatkan bahwa sebagian besar ibu yang menjadi responden memiliki persepsi positif tentang imunisasi dasar, sebanyak 34 responden $(60,7 \%)$ dan yang memiliki persepsi negatif sebanyak 22 responden $(39,3 \%)$.

Persepsi yang dibangun dengan baik mengenai imunisasi memiliki peluang untuk mengambil keputusan dalam melakukan imunisasi pada anak. Pengambilan keputusan dan kualitas 
JOURNAL OF HEALTH RESEARCH SCIENCE

VOL. 01 NO. 02, DESEMBER 2021

DOI: $\underline{10.34305 / J H R S . V 1 I 02.372}$

dari pilihan tersebut sebagian besar dipengaruhi oleh persepsi mereka (Isamaniar, 2015). Pada penelitian ini, dari keterangan Bidan Desa Paninggaran menyatakan bahwa responden yang memiliki persepsi positif tentang imunisasi memiliki antusias yang baik dalam kegiatan posyandu sehingga ibu menjadi lebih banyak mendapat informasi yang tepat tentang imunisasi dan motivasi yang baik untuk melakukan imunisasi pada bayinya. Hal ini lambat laun dapat meningkatkan pengetahuannya. Ibu yang memiliki usia yang matur membuatnya dapat berpikir dengan lebih beralasan dan memiliki pola pikir yang matang tentang pentingnya memberikan imunisasi anak (Aprilia et al., 2018).

Pada ibu yang memiliki persepsi negatif tentang imunisasi sebagian besar dari responden beranggapan bahwa imunisasi cukup dilakukan hanya 1 atau 2 kali suntikan saja sehingga hal tersebut tidak sesuai dengan anjuran serta kurangnya partisipasi ibu dalam melakukan kunjungan ke posyandu menjadi salah satu faktor penyebab ibu kurang memiliki pandangan dan motivasi yang lebih baik tentang
Ciptaan disebarluaskan di bawah Lisensi Creative

CommonsAtribusi-NonKomersialBerbagiSerupa 4.0

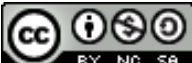

imunisasi. Selain itu menurut peneliti, faktor dari tingkat pendidikan dapat mempengaruhi persepsi ibu tentang imunisasi. Responden pada penelitian ini sebagian besar memiliki tingkat pendidikan yang cukup tinggi yaitu SMA sejumlah 21 responden $(37,5 \%)$ sehingga responden yang sebagian besar pendidikannya pada tingkat SMA cenderung memiliki persepsi positif tentang imunisasi.

Sejalan dengan penelitian $\mathrm{F}$. Rahmawati \& Sufriani (2020) dengan judul penelitian "Persepsi dan Perilaku Ibu tentang Imunisasi Dasar pada Anak di Aceh Besar" dengan p-value 0,000 menunjukkan bahwa ada hubungan persepsi tentang imunisasi dasar dengan perilaku ibu pada anak usia 10-24 bulan di wilayah kerja Puskesmas Kuta Baro Aceh Besar (F. Rahmawati \& Sufriani, 2020). Pada penelitian tersebut menyatakan bahwa tinggi rendahnya pendidikan ibu mempengaruhi perilaku ibu untuk mengimunisasikan anaknya yang dapat dipengaruhi oleh pengalaman dan saling tukar pikiran antara sesama ibu yang mempunyai anak, yang mana akan menciptakan sesuatu yang positif dan mengakibatkan ibu tersebut termotivasi untuk 
JOURNAL OF HEALTH RESEARCH SCIENCE

VOL. 01 NO. 02, DESEMBER 2021

DOI: $\underline{10.34305 / \mathrm{JHRS} . V 1 \mathrm{I} 02.372}$

mengimunisasikan anaknya yaitu dengan cara datang serta membawa anaknya ke Puskesmas.

2. Gambaran Kelengkapan Imunisasi Dasar pada Bayi usia 9-11 bulan

Dari hasil penelitian didapatkan sebagian besar ibu tidak melengkapi imunisasi dasar pada bayinya sebanyak 31 responden $(55,4 \%)$ dan yang melengkapi imunisasi dasar pada bayinya sebanyak 25 responden $(44,6 \%)$.

Kelengkapan imunisasi dasar pada bayi dipengaruhi oleh beberapa faktor salah satunya yaitu kurangnya pengetahuan ibu tentang imunisasi, yang berdampak pada kurangnya pemahaman ibu terhadap kelengkapan imunisas dasar. Faktor pengaruh kurangnya pengetahuan serta pemahaman didasari oleh tingkat pendidikan ibu (Sulistyoningrum \& Suharyo, 2017). Ibu yang menjadi responden dan tidak melengkapi imunisasi pada anaknya memiliki tingkat pendidikan rendah sampai dengan sedang.

Selain itu dari beberapa anggapan responden yang imunisasi pada bayinya tidak lengkap dikarenakan pengaruh suami atau keluarga yang
Ciptaan disebarluaskan di bawah Lisensi Creative

CommonsAtribusi-NonKomersialBerbagiSerupa 4.0

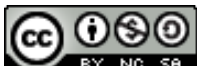

melarang untuk tidak melakukan imunisasi pada bayinya. Hal ini didukung dengan temuan dari beberapa responden yang tidak melengkapi imunisasi pada bayinya karena pengaruh suami yang didasari oleh pandangan suami yang masih kurang baik tentang imunisasi, sehingga responden terpengaruh akan pandangan tersebut.

Sejalan dengan penelitian A. I. Rahmawati \& Wahyuni (2014) dengan judul penelitian "Faktor yang Mempengaruhi Kelengkapan Imunisasi Dasar di Kelurahan Krembangan Utara" bahwa hasil penelitian menunjukkan kelengkapan status imunisasi dipengaruhi dukungan keluarga dengan hasil p-value 0,001 (A. I. Rahmawati \& Wahyuni, 2014). Pada penelitian tersebut menyatakan bahwa responden yang memiliki bayi atau balita dengan status imunisasi tidak lengkap sebagian besar tidak mendapat dukungan dari keluarganya, dan hal itu bertolak belakang dengan responden yang memilki bayi atau balita dengan status imunisasi lengkap yang sebagian besar mendapat dukungan dari keluarga, namun ada pula keluarga didalamnya tidak mendukung tetapi pengetahuan 
JOURNAL OF HEALTH RESEARCH SCIENCE

VOL. 01 NO. 02, DESEMBER 2021

DOI: $\underline{10.34305 / \mathrm{JHRS} . V 1 \mathrm{I} 02.372}$

ibu tergolong baik sehingga ibu dapat memberikan pelayanan kesehatan bagi bayi atau balitanya.

3. Hubungan Persepsi Ibu tentang Imunisasi dengan Kelengkapan Imunisasi Dasar pada Bayi usia 9-11 bulan di Desa Paninggaran Kecamatan Darma tahun 2021

Berdasarkan dari hasil analisis statistik menggunakan uji chi-square diperoleh $p$-value sebesar 0,000 atau ( $p$ $\leq 0,05)$, maka dapat diartikan bahwa ada hubungan antara persepsi ibu tentang imunisasi dengan kelengkapan imunisasi dasar pada bayi usia 9-11 bulan di Desa Paninggaran Kecamatan Darma tahun 2021. Nilai odds ratio (OR) yaitu 3,778 artinya ibu yang memiliki persepsi negatif tentang imunisasi mempunyai peluang berisiko 3 kali lipat untuk ibu tidak melengkapi imunisasi dasar pada bayinya dibandingakan responden yang memiliki persepsi positif tentang imunisasi. Data menunjukkan bahwa dari 34 responden yang memiliki persepsi positif tentang imunisasi sebagian besar kelengkapan imunisasi dasar pada bayinya lengkap yaitu 25 responden $(73,5 \%)$ dan yang tidak lengkap yaitu 9 responden (26,5\%).
Ciptaan disebarluaskan di bawah

Lisensi Creative

CommonsAtribusi-NonKomersialBerbagiSerupa 4.0

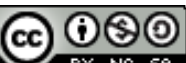

Dari 22 responden yang memiliki persepsi negatif tentang imunisasi secara keseluruhan kelengkapan imunisasi dasar pada bayinya tidak lengkap yaitu 22 responden (39,3\%).

Pada responden yang berpersepsi negatif berjumlah 22 reponden memiliki kecenderungan untuk tidak melengkapi imunisasi dasar pada bayinya. Sedangkan responden dengan persepsi yang positif tetapi tidak melengkapi imunisasi dasar pada bayinya sebagian besar mengikuti perintah suami untuk tidak melakukan imunisasi pada bayinya. Petugas puskesmas sudah memberikan informasi yang cukup baik melalui penyuluhan dan edukasi yang dilakukan saat kegiatan posyandu bila dilihat dari beberapa responden mengetahui manfaat dari imunisasi tetapi karena orang terdekat dari ibu yang memiliki bayi yaitu keluarga dan suami kurang mendukung sehingga membuat responden tidak melengkapi imunisasi pada bayinya. Berdasarkan penelitian ini, ibu yang melengkapi imunisasi dasar pada bayinya sebagian besar memiliki persepsi yang positif tentang imunisasi dasar. 
JOURNAL OF HEALTH RESEARCH SCIENCE

VOL. 01 NO. 02, DESEMBER 2021

DOI: $\underline{10.34305 / J H R S . V 1 I 02.372}$

Penelitian ini sejalan dengan penelitian Dillyana \& Nurmala (2019) dengan judul "Hubungan Pengetahuan, Sikap dan Persepsi Ibu dengan Status Imunisasi Dasar di Wonokusumo" yang menunjukan adanya hubungan antara persepsi ibu dengan kelengkapan imunisasi dasar pada bayi dengan $p=$ value $\quad 0,001 . \quad$ Persepsi ibu berhubungan dengan status kelengkapan imunisasi dasar pada bayi. Ibu yang memiliki persepsi positif akan berdampak pada status kelengkapan imunisasi dasar pada bayi, sebaliknya ibu yang berpersepsi negatif maka berdampak pada ketidaklengkapan status imunisasi dasar pada bayi (Dillyana \& Nurmala, 2019). Hasil penelitian ini selaras juga dengan penelitian Bachtiar \& Zahroh (2017), yang menyatakan bahwa persepsi yang tinggi akan mendorong suatu motivasi yang baik untuk melakukan suatu kegiatan, salah satunya seorang ibu yang baru saja melahirkan membutuhkan persepsi yang tinggi baik dari faktor internal dan eksternal untuk memotivasinya agar melakukan suatu kegiatan tertentu dalam mencapai tujuan dengan cara memberi imunisasi dasar lengkap pada bayinya (Bachtiar \&
Ciptaan disebarluaskan di bawah Lisensi Creative

CommonsAtribusi-NonKomersialBerbagiSerupa 4.0

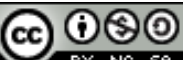

Zahroh, 2017). Selain itu persepsi orang tua sangat penting untuk meningkatkan kepatuhan terkait setiap pelaksanaan pelayanan kesehatan (Agustiani et al., 2017).

Persepsi merupakan salah satu hal yang dapat membangun ibu dalam pemberian imunisasi kepada anak, sehingga pandangan yang baik dan benar tentang imunisasi akan mendorong dan memotivasi ibu dalam melakukan imunisasi pada bayinya. Persepsi keseriusan sering didasarkan pada informasi medis atau pengetahuan, juga dapat berasal dari keyakinan seseorang bahwa ia akan mendapat kesulitan akibat penyakit dan akan membuat atau berefek pada hidupnya secara umum (Priyoto, 2013). Pengaruh persepsi terhadap pemberian imunisasi pada bayi tidak hanya terletak pada ibu saja, tetapi pada keluarga maupun masyarakat secara luas sekalipun. Pandangan yang baik tentang imunisasi dari berbagai pihak dapat membangun dukungan dan motivasi bagi ibu untuk dapat memberikan imunisasi kepada bayi secara lengkap dan tepat, untuk menjadikan anak-anak memiliki kesehatan dan kekebalan tubuh yang 
JOURNAL OF HEALTH RESEARCH SCIENCE

VOL. 01 NO. 02, DESEMBER 2021

DOI: $\underline{10.34305 / J H R S . V 1 I 02.372}$

baik sekarang maupun dimasa mendatang.

\section{Kesimpulan}

Berdasarkan hasil penelitian dapat ditarik kesimpulan bahwa terdapat hubungan antara Persepsi Ibu tentang Imunisasi dengan Kelengkapan Imunisasi Dasar pada Bayi usia 9-11 bulan di Desa Paninggaran Kecamatan Darma tahun 2021.

\section{Saran}

Saran yang dapat dikemukakan dalam penelitian ini adalah pengaruh persepsi terhadap pemberian imunisasi pada bayi tidak hanya terletak pada ibu saja, tetapi pada keluarga maupun masyarakat secara luas sekalipun. Pandangan yang baik tentang imunisasi dari berbagai pihak dapat membangun dukungan dan motivasi bagi ibu untuk dapat memberikan imunisasi kepada bayi secara lengkap dan tepat.

\section{Daftar Pustaka}

Agustiani, Noor, \& Ruswanti. (2017). Komunikasi Orang Tua Tentang Pendidikan Kesehatan Reproduksi dengan Persepsi Anak terhadap Pernikahan Usia Dini. Jurnal Ilmiah Ilmu Keperawatan Indonesia, 7(03), 179-190.

Aprilia, R., Herlina, Idayanti, T., Virgia, V., \& Yuliani, A. (2018). Hubungan
Ciptaan disebarluaskan di bawah Lisensi Creative

CommonsAtribusi-NonKomersialBerbagiSerupa 4.0

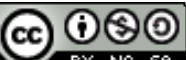

pengetahuan dengan sikap ibu tentang imunisasi difteri pada anak balita di desa jatiwates kecamatan tembelang kabupaten Jombang. Nurse Heal J Keperawatan, 31-41.

Bachtiar, I. A., \& Zahroh, C. (2017). Hubungan Persepsi Ibu dengan Imunisasi Campak pada Bayi usia diatas 9 bulan di Posyandu Mojowuku Slempit Gresik. Jurnal Ilmiah Kesehatan, 10(01).

Badriah, D. L. (2019). Metodologi Penelitian Ilmu-Ilmu Kesehatan. Multazam.

Bernsen, R. M., Al-Zahmi, F. R., Al-Ali, N. A., Hamoudi, R. O., Ali, N. A., Schneider, Jamal, Grivna, J., \& Michal, A.-M. and. (2011). Knowledge, Attitude and Practice towards Immunizations among Mothers in a Traditional City in the United Arab Emirates. Journal of Medical Sciences.

Dewi, A. P., D., E., \& Edison. (2013). Hubungan Tingkat Pengetahuan Ibu dengan Pemberian Imunisasi Dasar Lengkap pada Bayi di Kelurahan Parupuk Tabing Wilayah Kerja Puskesmas Lubuk Buaya Kota Padang Tahun 2013. Jurnal Kesehatan Andalas, 3(2), 114-118.

Dillyana, T. A., \& Nurmala, I. (2019). Hubungan Pengetahuan, Sikap dan Persepsi Ibu dengan Status Imunisasi Dasar di Wonokusomo. Jurnal Promkes: The Indonesian Journal of Health Promotion and Health Education, $\quad 7(1)$. https://doi.org/10.20473

Dinkes. (2019). Profil Kesehatan Jawa Barat Tahun 2019. Dinkes Jabar. 
JOURNAL OF HEALTH RESEARCH SCIENCE

VOL. 01 NO. 02, DESEMBER 2021

DOI: $\underline{10.34305 / J H R S . V 1 I 02.372}$
Ciptaan disebarluaskan di bawah

Lisensi Creative

CommonsAtribusi-NonKomersial-

Heriana, C. (2018). Epidemiologi : Prinsip,

Metode, dan Aplikasi dalam

Kesehatan Masyarakat (Wildan (ed.)).

PT Refika Aditama.

Isamaniar, H. (2015). Manajemen Unit Kerja: untuk Rekam Medis dan Informatika Kesehatan Ilmu Kesehatan Masyarakat Keperawatan dan Kebidanan. Deepublish.

Priyoto. (2013). Teori Sikap dan Perilaku Dalam Kesehatan. Nuha Medika.

Proverawati. (2010). Imunisasi dan Vaksininasi. Nuha Medika.

Rahmawati, A. I., \& Wahyuni, C. U. (2014). Faktor yang Mempengaruhi Kelengkapan Imunisasi Dasar di Kelurahan Krembangan Utara. Jurnal Berkala Epidemiologi, 2.

Rahmawati, F., \& Sufriani. (2020). Persepsi Dan Perilaku Ibu Tentang Imunisasi Dasar Pada Anak Di Aceh Besar. Idea Nursing Journal, 6.

Sulistyoningrum, D., \& Suharyo. (2017). Kelengkapan Imunisasi Dasar Pada Bayi Usia 9-12 Bulan Dan Faktor Determinan Di Kelurahan Randusari Kota Semarang Tahun 2017. Fakultas Kesehatan Universitas Dian Nuswantoro. 